Binghamton University

The Open Repository @ Binghamton (The ORB)

$12-1-2018$

\title{
The Development of County HR Policies: The Perspectives of Counties in Two States
}

Willow S. Jacobson

The University of North Carolina at Chapel Hill

Kristina T. Lambright

Binghamton University--SUNY, klambrig@binghamton.edu

Follow this and additional works at: https://orb.binghamton.edu/public_admin_fac

Part of the Public Administration Commons

\section{Recommended Citation}

Jacobson, Willow S. and Lambright, Kristina T., "The Development of County HR Policies: The Perspectives of Counties in Two States" (2018). Public Administration Faculty Scholarship. 50.

https://orb.binghamton.edu/public_admin_fac/50

This Article is brought to you for free and open access by the Public Administration at The Open Repository @ Binghamton (The ORB). It has been accepted for inclusion in Public Administration Faculty Scholarship by an authorized administrator of The Open Repository @ Binghamton (The ORB). For more information, please contact ORB@binghamton.edu. 


\title{
The Development of County HR Policies: The Perspectives of Counties in Two States
}

\begin{abstract}
We conducted 40 semi-structured interviews with county HR directors (20 in New York, 20 in North Carolina) to learn more about the development of internal HR policies. Key resources used by directors in both states include other jurisdictions, colleagues in other county departments, state and federal agencies, laws and statutes, professional associations, and information gathered from general internet searches. More than half of the HR directors reported using internal working groups, and almost two-thirds indicated that they systematically reviewed the implications of policies for specific departments. Yet, only a handful of HR directors reported utilizing other promising practices such as engaging rank-and-file employees in the policy process, reviewing a new or revised policy's consistency with existing policy, and using evidence-based decision-making to develop policies. While there was little difference by state, our findings indicate the characteristics of HR directors can shape how a jurisdiction approaches policymaking.
\end{abstract}




\section{The Development of County HR Policies: The Perspectives of Counties in Two States}

Organizations continue to face a range of challenges including changing demographics, economic concerns, and political pressures. Chief among these is having a workforce with the skills and expertise needed to perform core organizational functions. Growing research speaks to the critical role human resource management (HRM) can play in ensuring short-term and longterm organizational effectiveness (Becker \& Gerhart, 1996; Ulrich \& Brockbank, 2005; Jacobson \&Sowa, 2016; Kellough, 2017). Crafting an appropriate job posting, ensuring the selection process is rigorous and meets all legal requirements, and hiring a qualified candidate are simply the first steps in the employment life-cycle. Once hired, employees need to be oriented, trained, motivated, and at times disciplined. HR departments and policies influence each step of this process. HR policy formation if done correctly serves as a crucial strategic tool for managing an organization's workforce. Internal organizational policies influence those working within public organizations as well as the results those organizations are able to produce.

Despite considerable scholarly interest in specific HR policies and their impact on employees and organizations, there has been surprisingly little empirical investigation of the process practitioners use to develop these policies. Specifically, we do not know the type of resources HR managers consult, which stakeholders are involved in the process and the extent to which policies are evaluated prior to implementation. Are managers going beyond simple information gathering and utilizing practices that make the process more inclusive and assess the potential policy impact on their organization? Learning about the policymaking strategies HR departments use may be particularly helpful for current practitioners when they are deciding how to structure their own processes and make them more aware of possible practices they may want to adopt. 
To better understand how HR policies are developed, we conducted 40 semi-structured interviews with county HR directors in two states: 20 interviews in New York and 20 interviews in North Carolina. We examined both the information resources and strategies HR directors utilized when developing policy. We also created an index based on use of promising practices and assessed whether respondent or jurisdictional characteristics help explain policy process choices. Our research provides important insights into HR practices of county government, a level of government which several scholars have noted is understudied (Benton, 2005; Streib et al, 2007; Svara, 1996). We begin by summarizing past research on HR policies as well as discussing several strategies scholars identify as promising. Next, we present our methods and key findings. Finally, we explore the implications of our study and highlight several areas for future research.

\section{Approaches to HR Policymaking and Promising Practices}

HR scholars often recommend formalizing or codifying practices or desired behaviors into a policy. However, they do not typically specify the resources that should be consulted when creating the policy or how the process of writing it should be approached. For example, Bradbury and Facer (2010) note when talking about workplace ethics that "the overarching practical recommendation for managing an ethically robust at-will employment relationship is to implement a policy and set of behaviors that exceed legal obligation (p. 281)." There are a variety of resources and strategies managers could potentially utilize when developing ethics policies but still little is known about how they approach this process in practice. Similarly, while HR scholarship has focused on constitutional and legal requirements in the public sector (Hartman, Homer, \& Reff, 2010; Hoyman \& McCall, 2010; Ledvinka, 2010; Riccucci, 2010; Rosenbloom \& Chanin, 2016), it does not explore how these constitutional and legal issues 
impact the development of jurisdictional policies. Rather than examining the policy development process, research on HR policy has focused on the impact of specific policies or practices on outcomes (Bae \& Yang, 2017; Battaglio \& French, 2016; Caillier, 2016; Facer \& Wadsworth, 2008; Facer, Wadworth, \& Arbon, 2010; Galinsky \& Stein, 1990; Grover \& Crooker 1995; Honeycutt \& Rosen 1997; Huselid, 1995; Otenyo \& Smith, 2017; Selden \& Moynihan 2000; Wadsworth \& Facer, 2016), policy and innovative behaviors (Searle \& Ball, 2003) and comparative policies and practices (Kopp, 1994).

Although past scholarship does not directly address the HR policy formation process, it does provide insights into possible ways this process may be approached. Two important decisions HR managers must make are what information resources they should consult and how many resources will be adequate. While ideally decision makers would gather as much relevant information as possible in order to make the best decision, humans in the real world have cognitive limits and ultimately must "satisfice" in their information search (Simon, 1947). Drawing on seminal work by DiMaggio and Powell (1982), isomorphic pressures may at least partially influence the information managers seek as part of their search. According to DiMaggio and Powell (1982), organizations within a field are often quite similar due to three key processes. These processes involve organizations': (1) acting in response to formal or informal pressure from external constituencies that oversee or regulate them, referred to as coercive isomorphism; (2) imitating "best practices" used by comparable entities, referred to as mimetic isomorphism; and (3) adopting policies consistent with professional norms and values, referred to as normative isomorphism. Considering DiMaggio and Powell's framework in this context, one would expect local HR managers to gather information about state and federal agencies' 
expectations, other counties' practices and professional norms when developing policy. These resources may or may not be used in conjunction with information from other sources.

Past scholarship while not investigating the HR policymaking process specifically also identities a number of strategies that are suggested as promising practices which HR managers may want to use in policy development. These strategies involve more than information gathering. For example, a key consideration when developing policies is the extent to which the process is inclusive. When designing policy, receiving feedback from varied perspectives may increase its efficacy. Research on diverse teams has demonstrated that inclusive teams that are more heterogeneous in composition are more likely to be successful in accomplishing their tasks and identifying new ideas (Phillips, Liljenquist \& Neale, 2009). Consistent with this, Stewart and Brown (2011) stress the importance of encouraging diversity in ideas and thoughts in HR decision-making and note that "making sure that the team of decision makers includes people with different backgrounds can help (p. 45).”

In addition, scholars have highlighted the benefits of engaging employees in policymaking processes (Adler \& Borys, 1996; DeHart-Davis, 2009, 2017; Fernandez, Resh, Moldogaziev, \& Oberfield, 2015; Sabharwal, 2014; Stivers, 2008; Whitener, Brodt, Korsgaard, \& Werner, 1998). The inclusion of those who will need to comply with a policy or enforce it is important in order for a policy to be effective. Employees can offer valuable insights into the reality of day-to-day operations critical for policy design (Stivers, 2008). Including stakeholders in the policy development process can also increase compliance once a policy is implemented and make it more likely that the policy will be perceived as fair (Adler \& Borys, 1996; Kim \& Mauborgne, 1998; Rubin, 2007). Research on the design of effective performance appraisal systems offers empirical support for the importance of seeking feedback from the workforce and 
has found these complex and often controversial processes are improved through greater and more diverse stakeholder involvement, including input from employees (Mohrman, ResnickWest, \& Lawler, 1989; Roberts, 2003; Rubin, 2009).

While seeking feedback from a variety of stakeholders is beneficial, it is critical to ensure that policies align with organizational needs. Over the past two decades, several scholars have argued that HR managers should not just focus on compliance and regulation as they traditionally have but also move to be strategic partners on the executive team allowing HRM to better help organizations align their workforce to achieve their strategic and organizational goals (Daley, 2006; Jacobson \& Sowa, 2016; Lim,Wang, \& Lee, 2017; Pynes, 2009; Selden, 2009). Advocates of Strategic Human Capital Management (SHCM) emphasize the importance of aligning personnel policies and practices with an organization's strategic objectives and its other initiatives and policies (Jacobson, Sowa, \& Lambright, 2013; Pynes, 2009; Selden, 2009). In addition to considering consistency with existing policy, HR managers should review policy implications for individual departments within an organization. As an illustration, Daley (2012) notes when discussing work-life policies: "HR specialists must consider the circumstances of offering work-life policies across work units. For example, flexible working hours may be easily implemented in a city's utilities unit but might create chaos within the police or fire units" (p. 70).

Another central tenet of SHCM is that HR decisions should be evidence-based (Pfeffer \& Sutton, 2006; Rousseau \& Barends, 2011; Selden, 2009). As explained by Selden (2009), HR professionals should collect data using relevant and reliable measures and utilize this information to make decisions. Consistent with arguments made by SHCM scholars, Roberts (2010) advocates for the use of research methods and evaluation in the HR decision-making process. 
Furthermore, Clardy (1997) asserts that HR policy and practices are improved when practitioners gather information from formal data collection methods and use it as part of their decisionmaking process. While SHCM proponents have promoted the benefits of evidence-based decision making, the use of analytics may be difficult in practice as other scholars have demonstrated the challenges of actually using performance information in public organizations (Ammons \& Rivenbark, 2008; Arnaboldi, Lapsley, \& Steccolini, 2015; Hall, 2017; Poister, Pasha \& Edwards, 2013). Despite scholars recognizing the importance of HR policy as a managerial tool, there has been little systematic empirical investigation of how HR professionals approach policymaking. Our research aims to address this gap in our knowledge by examining the information resources and process county government HR managers utilize when developing internal HR policies, including their use of the promising practices identified in this literature review.

\section{Research Design}

We conducted semi-structured phone interviews with 40 county HR directors: 20 from New York and 20 from North Carolina. We used a "diverse" case approach when selecting these two states (Seawright \& Gerring, 2008). Our goal was to examine the HR policymaking process in two very different contexts so we could explore how, if at all, environmental differences influence internal county HR policymaking processes. New York and North Carolina were good choices for this comparative case study design because they are from different regions and vary in terms of their political culture, county civil service laws, and the role of collective bargaining and union activity in the public sector.

Counties in these two states were randomly selected from jurisdictions with workforces of 500 employees or greater. We excluded counties located in New York City. These counties 
were omitted from the sampling frame because the size and function of government in New York City is on a different scale compared to the other counties in New York and North Carolina and could introduce confounding factors into our analysis. We limited our sampling frame to counties with workforces greater than 500 employees to ensure a county's workforce would be of sufficient size to warrant a need for a county-level HR director. We also felt it was important to have a minimum workforce size to increase the probability that our respondents would be involved in policymaking decisions that were sophisticated enough to enable them to answer our interview questions.

Our sample represents $41 \%$ and $45 \%$ of the counties eligible to be included in our study from New York and North Carolina, respectively. While collecting our data, we observed a high level of data saturation. Based on a review of the data conducted after approximately 30 interviews, we found respondents were consistently identifying the same key themes. After completing an additional ten interviews, we reviewed the responses and found no new patterns emerging from the data. At this point, we had achieved the intended coverage of our sampling frame (more than $40 \%$ of eligible counties were included from both states) and were confident that we had reached data saturation. The counties included in our sample had populations ranging from 29,967 to $1,419,369$ with a median of 117,154 and workforce sizes ranging from 500 to 11,735 with a median of 974 . The smallest HR department had 2 employees while the largest had 120 employees; $68 \%$ had 10 or fewer employees. Table 1 compares our sample and counties that were eligible to be included but were not selected in terms of population, workforce size, poverty rate, and median household income. As this table indicates, the medians for these two groups are generally similar for each of these demographic characteristics.

<Table 1 about here.> 
At the start of each interview, we guaranteed confidentiality. The average interview lasted 45 minutes. We asked respondents to first think of the most recent policy they had helped to develop or revise. ${ }^{1}$ The types of policies respondents discussed varied considerably. Examples included policies related to workplace violence, the Family Medical Leave Act, harassment and discrimination, substance abuse, and ethics. In addition, the impetus for creating or revising the policies varied. Several directors indicated that they were responding to mandates from either the state or federal government. Others described policy changes that were internally-driven.

Respondents were asked to describe the process used to develop the policy they identified, including what information they had used and what individuals were involved. As part of this discussion, we asked respondents what information resources they felt were the most helpful. Next, we asked respondents to describe the typical process that they used to develop policies if it was different from the process they had used for the specific policy example. In addition, respondents were asked to describe any situations in which their approach to policy development might be different. We asked the questions about the typical policymaking process and about unusual situations to ensure we had a comprehensive understanding of the variety of practices each county used to develop HR policies. For this research, we were interested in learning about a county's overall policy process. Our unit of analysis is not the approach a jurisdiction took with one specific policy but rather the full range of activities, resources, and strategies they employed when developing HR policies. Finally, we collected information about the jurisdictions and the respondents' professional backgrounds. Slightly less than half of our respondents $(45 \%)$ had worked in the private sector previously, and $60 \%$ were members of 
national professional associations. Tables 2 and 3 provide further background information about respondents.

<Tables 2 and 3 about here.>

All interviews were recorded and transcribed, and data were analyzed using the qualitative data analysis software QSR NVivo. We developed coding definitions in order to ensure consistent code usage and utilized both pattern-matching (Yin, 1994) and memoing (Miles \& Huberman, 1994) in our data analysis. Both researchers independently coded all of the interview data and then reviewed this information together to resolve any coding discrepancies. In addition to qualitatively analyzing the data, we developed an index to measure the extent to which counties were using strategies that were consistent with the practices identified as promising in the literature review. We describe the components of this index in detail in our findings. We ran several t-tests and basic correlations to assess whether there were any patterns involving the index scores and the characteristics of the respondents or the county for which they worked.

This study's research design enabled us to collect rich qualitative data and examine the HR policymaking process in two states with very different political, social, and economic characteristics. However, there are some limitations to the research design. This study is exploratory as there is little empirical research on this paper's topic. With 40 interviews, we are not able to provide definitive answers to our research questions. The power of the inferential statistical tests we ran was also low due to the small size of our sample. Another limitation is that county HR directors' utilization of information resources in New York and North Carolina may not be representative of the resources used by other types of public managers or county HR directors in other states. Finally, we have no outcome measures on policy efficacy. As a result, 
we are unable to assess if using promising practices identified in the literature review actually makes policies more effective.

\section{Findings}

We begin by describing the information resources HR directors used to develop policies. Next, we provide an overview of the extent to which counties employed strategies consistent with the promising practices identified in the literature review. We conclude this section by developing an index based on the use of these promising practices and examining whether there are any relationships between the county's policymaking process and respondent or jurisdictional characteristics.

\section{Information Resources}

Respondents used a wide array of resources when creating or revising policies. Table 4 details, by state, the frequency with which various information resources were used in the policymaking process. Counties were recorded as utilizing a resource if respondents mentioned ever consulting it in the policy development process, not just if they mentioned using it in the specific policy example they described at the beginning of the interview. On average when working on policy, HR directors drew on six different resources, ranging from a low of three resources to a high of ten resources. Besides indicating that they personally helped create policies and relied on their own internal HR staff, directors reported other county staff and officials were often involved in policymaking (See Table 4). Of the 40 HR directors, 24 (60\%) received feedback from county attorneys or retained council, $22(55 \%)$ from the county executive or executive staff, 34 (85\%) from other county staff subject matter experts (including department heads, union representatives ${ }^{2}$, and specific county employees with specialized knowledge in the policy area being explored) and $11(28 \%)$ from boards or legislatures. ${ }^{3}$ North 
Carolina HR directors were more likely to consult the county executive or executive staff but use of other internal resources was comparable by state. Several respondents indicated the information they received from internal sources was extremely helpful. As an example, one respondent reported:

You learn there are people [internally] who have been doing this kind of stuff for years. They are good at it and know a lot more than some others, and they are a tremendous asset to the process. They are able to analyze documents provided by the consultant or challenge with real life experiences that may say maybe it worked somewhere else but we'll tell you why it didn't work here and what we did to counteract why it didn't work here. I find the department people are the experts and are invaluable to developing any kind of policy.

<Table 4 about here. $>$

In addition, respondents utilized a variety of external information resources when developing or revising policy. The most common was personnel and policies from other jurisdictions: thirty-six respondents (90\%) reported consulting other jurisdictions in the policy development process. Respondents emphasized they wanted to learn from other counties' experiences. Reflecting the sentiments of many, one respondent commented: "We try to seek out similarly situated governments and see what they do and we'll learn from their experiences. We try to find a template so we don't have to reinvent the wheel." While many directors relied heavily on their colleagues from other jurisdictions in the policymaking process, some recognized limitations with this approach and noted that strategies which work in one jurisdiction may not necessarily work in another if there are considerable differences in the characteristics of the counties. These directors indicated they were careful to modify policies when necessary to meet the needs of their jurisdiction before adopting them. As one of these respondents explained: “I realize what works for some counties won't always work for us so I like to have samples of policies from other counties and just kind of tailor them to our needs." 
Consistent with the fact that directors frequently reported they created or revised policy because of an external mandate, many respondents used state and federal governments as key resources in the policymaking process. More than half of the directors (55\%) mentioned either calling representatives from state or federal agencies or consulting their websites. Respondents thought the guidelines and policy templates provided by these agencies were particularly useful. According to one respondent:

They [the state] had a template in place. They had already documented the process so it made the research easier. We had a template to use as a guide so the rest was based on our own particular needs. It was a good starting point.

In addition, nineteen respondents (48\%) reported reviewing laws and general statutes from both the state and federal government to develop policy. Respondents used these legal documents as references to clarify what they could and could not do when creating a policy as well as what they had to do.

Another key resource was the internet with nineteen directors reporting they routinely conducted general internet searches as part of the policy development process. In fact, many of these respondents indicated this was the first thing they did. In the words of one respondent: "No, I wish I could say there was a particular site but normally I just Google the area. For example, social media, I'll Google that." Others did more tailored searches. For instance, one respondent commented: "What I generally do is if I can't find links through the appropriate website on the internet, I will Google search a topic and look for a site I trust based on what I used in the past." While generally viewed as an important information resource for many, some respondents noted that the usefulness of the internet did vary depending on the policy. As an example, one respondent reported: "When we did our Family Medical Leave, there was a lot of material on the net, where something like nepotism is not really out there." 
Professional associations were also important resources with eighteen respondents (45\%) indicating they had used information from these organizations when developing or revising policy. Directors were most commonly utilizing resources from national professional associations such as the Society for Human Resource Management and the International Personnel Management Association. Some respondents reported professional associations provided helpful policy templates while others described using professional associations as more general sources of information in the policymaking process.

While the frequency with which different external information resources were used was quite similar across the two states, there was one important exception. None of the respondents from New York mentioned consulting academic personnel or publications when developing policy. On the other hand, twelve North Carolina HR directors (60\% of the North Carolina sample) reported using academic resources although all of these respondents had received information from the same academic institution: the School of Government at the University of North Carolina at Chapel Hill. ${ }^{4}$ Several respondents reported the assistance they had received from this resource was helpful. For example, one North Carolina HR director commented: "We use [the School of Government] all the time. [School of Government faculty X] is on my speed dial." None of the New York or North Carolina HR directors reported using academic resources from any other institutions in the policy development process.

Respondents reported that they typically used the same process to develop policies regardless of a policy's content. However, a handful of directors said they did tend to consult fewer resources when developing policies that were straightforward, such as when it is in response to a specific state mandate, compared to policies where there was more discretion. For example, one respondent commented: 
Unless something is spelled out so clearly in law that you don't have to expand on it, then I wouldn't go through this process. Most of the time you have to adopt what the legal requirements are to your actual setting.

Generally, directors reported that they had access to all of the information sources that they wanted.

When asked which resource was most useful, the following were the most frequently identified: other jurisdictions (thirteen counties), state or federal resources including laws and policy templates (eleven counties), and internal resources such as input from other department heads and county employees (six counties). Other respondents commented that the value of different resources varied depending on the policy. As one respondent noted, "I think in my experience in some cases the benchmarks are more helpful and then in other cases the stakeholder feedback."

Some of the external resources that managers mentioned using frequently as well as the resources that were identified as the most useful suggest isomorphic processes may be influencing county HR policymaking. Managers' use of state and federal agencies as well as laws and statues as key information resources aligns with coercive isomorphism. Similarly, managers' reliance on personnel and policies from other counties is consistent with mimetic isomorphism. It is also possible that managers' utilization of the internet may reflect mimetic isomorphism if the primary purpose of their searchers was to find policy templates from similar organizations. Finally, managers often consulted professional associations when developing policy, which could imply normative isomorphism. All 40 managers reported utilizing resources associated with at least one isomorphic process, with $80 \%$ using resources consistent with two or more isomorphic processes. 


\section{Use of Promising Practices in the Policymaking Process}

Are managers primarily focused on being expedient when designing policy, focusing on gathering information they think they need from a mix of internal and external sources and then writing policy? Or are they also using more sophisticated strategies that may help them tailor policies to their jurisdictions' needs and go beyond simple information gathering? According to our interviews, counties varied in the extent to which they used strategies consistent with promising practices described in our literature review. For instance, the degree to which counties' policymaking processes were inclusive differed. Directors in 21 counties (53\%) indicated that, at least sometimes, internal work groups composed of individuals from multiple departments were responsible for developing and writing HR policies (ten in North Carolina and eleven in New York). In the remaining counties, the policy development process was less inclusive, and the HR department was the primary policy author. Four of the counties with internal working groups had standing policy committees. As described by one of these directors:

We have a personnel committee....It is made up of the County Manager, one of the Commissioners and I will create the policy, meet with them, talk to them about the issues leading to the needs for a creation or revision and they will give input and decide if it's ready to take to the Board of Commissioners.

In the other seventeen counties, committees were specifically assembled based on the nature of the policy. As one of these directors explained:

There's not a big broad brush that can say we're going to pull together the same six departments to write every policy that we're doing. It really depends on the situation and what you're trying to resolve by creating the policy.

Both standing policy groups and ad hoc committees provided counties with a mechanism for systematically involving other voices in the policy-writing process beyond just the HR department and increasing the diversity of the decision-making team. The members of these internal working groups were generally senior management and department heads. 
Another strategy counties used to ensure that the policymaking process was inclusive and a variety of concerns were considered was to give rank-and-file employees opportunities to provide feedback. Seven directors (18\%) described employee engagement efforts (four from North Carolina and three from New York). Some counties had open comment periods during which any employee could offer input. Others indicated they specifically sought guidance from line staff potentially affected. As an example, one respondent explained the role staff play in the policy development process as "first just fact gathering, what has occurred and then what would they like to see occur."

In addition to trying to involve a variety of voices in policymaking, several counties mentioned strategies they used to ensure policies were thoroughly evaluated. The most common was to systematically review policy implications for departments with 26 counties $(65 \%)$ specifically mentioning they consider this when creating and revising policies (thirteen from both states). According to one of these respondents: "We have such a variety of employees. Talking to them [department heads] on how they would fit into such a policy and how it would affect them is beneficial." In some cases, departments were asked for their feedback to evaluate the feasibility of the policy once the policy had been developed: "After we research it and draft a policy, we send it to the department heads and ask for their feedback." In others, input from the department was the impetus for the policy: "Maybe the way we do things internally doesn't meet the needs of the department... so we look to make changes based on feedback from department heads." Less common than reviewing departmental implications, six directors reported that their counties (15\%) considered the new or revised policy's consistency with other existing policies (four in North Carolina and two in New York). As an example, one director commented when describing the development of his county's technology use policy: "We [also] have an external 
communications policy so there's back and forth to make sure things aren't contradictory and are consistent.” Finally, ten counties (25\%) reported systematically reviewing data and using evidence-based analysis to inform the policymaking process (six in North Carolina and four in New York). Typically, these counties were benchmarking their policies with those from other jurisdictions and private employers to ensure county policies were consistent and competitive.

\section{Policy Process Sophistication Index}

As part of our analysis, we developed an index to assess how counties structured their policy formation processes and measured the extent to which counties were using strategies consistent with the practices identified as promising in the literature review. These practices are more sophisticated as they go beyond simple information gathering. Our index has five components. Counties were given a point for each of the following policymaking strategies they utilized (these are not the same as the resources they draw on referenced in Table 4, but reflect process choices): (1) use (at least sometimes) of an internal working group to help develop policy (as a measure of team diversity), (2) engagement of rank-and-file employees in the policy process, (3) review of policy implications for individual departments, (4) review of the new or revised policy's consistency with existing policy, and (5) use (at least sometimes) of evidencebased decision-making to develop policies. The maximum potential score a county could receive on the index was a 5 . Table 5 provides descriptive statistics for the index and its components. As Table 5 illustrates, counties' scores ranged from zero to four with a mean score of 1.75, indicating the average county is using approximately two out of five promising practices. All four of the counties that received a zero on our index (i.e., those that had not adopted any of the promising practices) appear to be particularly reliant on resources aligned with isomorphic 
processes. At least half of the resources each of these counties were consulting fit this classification.

$<$ Table 5 about here.>

We examined whether there were any patterns between a county's sophistication index score and a variety of respondent characteristics including: education, certifications, membership in a national professional association, time in position, private sector work experience in HR and status as strategic partners. As Table 6 shows, the average index score was higher for respondents who had more education, had some type of certification, were members in a national professional association, had been in their positions for five or fewer years, had no private sector experience and were strategic partners (they were actively engaged in the county strategic planning process and their input was viewed as critical by executive county leadership). ${ }^{5} \mathrm{We}$ also explored whether a county's sophistication score was related to the following jurisdictional characteristics: state and HR department size. Counties in North Carolina and those with HR departments that had 11 or more staff had higher average index scores as Table 6 illustrates. According to a two-sample t-test, the difference between the index scores for respondents with and without private sector experience was significant $(\mathrm{p}<.05)$. In addition, there was a significant negative correlation between the respondent's time in their position and the county's score on the sophistication index $(\mathrm{p}<.05)$. None of the other respondent or jurisdictional characteristics were significant.

<Table 6 about here.> 


\section{Discussion and Conclusion}

This article provides important insights into the process county government HR professionals use to develop internal HR policies for their workforces. Our findings indicate county HR directors collect information from a combination of internal and external resources. Some key resources frequently used by directors in both states align with isomorphic processes, including other jurisdictions, state and federal agencies, laws and statutes from the state and federal government, and professional associations. Managers' reliance on these resources suggest they may at least in part be responding to pressure from oversight bodies, copying "best practices" of similar organizations and adopting current professional norms when developing policies. HR directors in both states also commonly consulted colleagues in other departments and the internet for information.

All but four of the counties included in our sample went beyond simple information gathering and utilized strategies consistent with at least one of the promising practices identified although there was considerable variation in the number different counties had adopted. Utilization of some strategies was common. For instance, more than half of the HR directors reported relying on internal working groups. This approach gives individuals from different departments an opportunity to influence policies, increasing the diversity of the decision-making team. In addition, almost two-thirds of the HR directors indicated that they systematically reviewed the implications of policies for specific departments. Implicit in the use of internal work groups and review of departmental implications is the recognition that different departments are likely to have different perspectives on the same policy and its impact.

On the other hand, other strategies were less commonly employed. Only a handful of HR directors reported utilizing each of the following strategies: (1) engaging rank-and-file 
employees in the policy process (18\%), (2) reviewing a new or revised policy's consistency with existing policy (15\%), and (3) using (at least sometimes) evidence-based decision-making to develop policies $(25 \%)$. These findings suggest that the directors could ask for more feedback from rank-and-file employees and policies could be more thoroughly evaluated in many of the counties studied. While internal working groups provide feedback from a variety of perspectives and composition of these groups varies, typically upper level managers serve on these committees. As a result, policy issues that are important to rank-and-file employees may receive less attention or be overlooked. Offering more opportunities for rank-and-file employees to give input may increase organizational buy-in and increase the likelihood that a policy is effective (DeHart-Davis, 2009; Stivers, 2008). Moreover, considering a policy's consistency with existing policies and using evidence-based decision-making can help counties tailor policies to match their specific needs and strategic goals.

Overall, the frequency with which different information resources were used was consistent across the two states with a few exceptions. The most notable was that only the North Carolina directors reported consulting academic publications or personnel in the policy formation process. The approach to policymaking and extent to which HR directors utilized different practices was also similar across states. The average score on the sophistication index was slightly higher for the North Carolina counties. However, this difference was not significant. The similarities in the information resources and practices used in the two states are quite interesting given unions play a much more prominent role in New York and the two states are very different in terms of their political, social, and economic characteristics. Our results may indicate that environmental factors such as these have minimal influence on internal county HR policymaking processes. 
While there was little difference by state, our findings suggest certain characteristics of HR directors matter and shape how a jurisdiction approaches the policy process. HR directors with private sector experience were significantly less likely to be using strategies included in our sophistication index. We often think of the private sector being ahead of the public sector in terms of more strategic behavior, making this an interesting and unexpected result (Ulrich, Brockbank, Johnson, Sandholtz, \& Younger, 2008; Lawler \& Boudreau, 2009). Two of our measures look at practices that are more inclusive in nature, and private sector organizations may place less emphasis on this value. Moreover, there is often less variation in the activities and outputs within private sector organizations compared to public sector ones. As a result, there may be less need to consider policy implications or use analytical tools to examine policy fit. In addition, HR directors who had been in their positions longer used significantly fewer strategies. More experienced HR directors may have greater confidence that they have a good sense of how various policies will impact their workforce and assume they do not need to seek feedback from a wide variety of stakeholders and closely examine policy implications. On the other hand, it is possible these directors are resistant to change or the use of new practices. The individual leading the HR department appears to play an important role in how a county approaches developing internal policies for its workforce. The results of this research are consistent with work by Jacobson, Sowa and Lambright (2013) that finds HR leadership is critical in SHCM implementation. Both studies underscore the importance of the leadership HR directors can provide.

In this research, we assess the overall sophistication of counties' HR policymaking process. Although we classify some counties as more "sophisticated" in their approach than others, even the counties that have adopted some of the more advanced strategies are unlikely to 
use them for every policy. In fact, uniform use of these practices would not necessarily be recommended. For instance, if a county is mandated by the state to implement a policy prohibiting smoking within 100 feet of a public building, there may be little need for the HR director to thoroughly vet the policy. It may be sufficient for the HR director to develop the policy primarily based on advice from colleagues in other county departments and using template policy documents from the state. On the other hand, HR directors may want to use a more deliberate approach in situations where HR directors have greater discretion such as with the development of a social media use policy. In this example, it may be helpful to: (1) seek information from many different sources (such as the IT and legal departments) and use an internal working group because this is a relatively new challenge for county governments with many potential implications, (2) consider employee buy-in early in the process, (3) collect data on job-related social media usage, (4) systematically assess policy impact on different departments and (5) carefully evaluate the fit with existing policies (such as those related to IT and public information) prior to implementation. The most appropriate approach for developing a particular policy depends on the characteristics of the jurisdiction, a jurisdiction's needs, and strategic goals as well as the policy itself.

Our findings suggest several areas for future research. Building on this exploratory study, scholars should consider how the policy formation process impacts HR policy results. As noted previously, we did not collect data on policy outcomes and were unable to explore whether the use of the promising practices identified actually made HR policies more effective. Researchers could also compare the efficacy of the various strategies we discussed and investigate whether some strategies are more effective than others. 
Another limitation of our study is its small sample size. The average index scores were considerably higher in counties where respondents had more education, had some type of certification, and were strategic partners. Even though the differences in these means were quite large, none were statistically significant, perhaps due to the low power of our statistical tests. Our results suggest that the preparation and philosophical approach of HR directors may matter in the policy formation process too. It would be interesting to examine in future research whether the same basic patterns we found could be replicated and whether the results would be statistically significant with a larger sample. Such results would provide further evidence that HR directors play an important role in the policymaking process. In particular, researchers may want to more closely examine the association between the sophistication of a county's policymaking process and the training HR directors receive. Findings of a relationship between these two variables would further suggest normative isomorphism is influencing HR policy formation as universities and other professional training institutions are critical in fostering shared norms and values within fields (DiMaggio \& Powell, 1982).

In addition, researchers may wish to explore some of the strategies we highlight in greater depth as this research looked at them as part of a broad overview of the policymaking process. For instance, collecting information from other jurisdictions was a very common practice and could be consistent with mimetic isomorphism. We are curious to what extent counties are really seeking feedback on best practices as opposed to just gathering information about any policy. We also wonder how, if at all, they are tailoring these policies. As another example, it would be interesting to find out more about the specific ways counties try to engage rank-and-file employees in the HR policymaking process. Are these efforts perfunctory or is county leadership actively seeking feedback and shaping HR policy based on employee input? 
The answers to these questions will provide a greater understanding of the process used to develop internal HR policies and will help local government HR professionals identify promising practices they may opt to utilize. These policies have an important and long-lasting impact on the culture and morale of the workforce. Learning more about how managers can strategically approach policymaking has the potential to improve the performance of public organizations.

Notes

${ }^{1}$ Pugh, Hickson, and Hining (1969) define formalization as "the extent to which rules, procedures, instructions and communication are written (p. 116)." This is important to note as in this research we are explicitly examining policies that have been formalized in a written process and adopted by a governing board.

${ }^{2}$ Only respondents from New York reported union representatives participated in the policymaking process. All state and local governments in North Carolina are prohibited from engaging in collective bargaining.

${ }^{3}$ In these cases, the board or legislature was involved in the policy design phases. This is not a reference to the formal adoption of a policy by the board or legislature.

${ }^{4}$ According to the school's website, it is "the largest university-based local government training, advisory, and research organization in the United States," offering courses, seminars and specialized conferences for public officials. There is no comparable system of support for local governments available through higher education institutions in New York.

${ }^{5}$ As part of our interviews, we talked with respondents about their counties' strategic planning processes. We specifically asked HR directors about their involvement in strategic planning in their county and the extent to which their county manager viewed HR as a strategic function, a support function or some combination of both. 


\section{TABLES}

Table 1: Comparison of Demographics for Sample and Counties Eligible to be Included but not Selected (All Medians)

\begin{tabular}{|c|c|c|c|c|}
\hline & Population & $\begin{array}{l}\text { Number of County } \\
\text { Employees }\end{array}$ & $\begin{array}{c}\text { Poverty Rate (2009- } \\
\text { 2013) }\end{array}$ & $\begin{array}{c}\text { Median } \\
\text { Household Income }\end{array}$ \\
\hline $\begin{array}{l}\text { Eligible NY } \\
\text { counties not in the } \\
\text { sample }\end{array}$ & 73,966 & 951 & $14 \%$ & 51,393 \\
\hline NY sample & 117,154 & 1,071 & $14 \%$ & 49,969 \\
\hline $\begin{array}{l}\text { Eligible NC } \\
\text { counties not in the } \\
\text { sample }\end{array}$ & 115,778 & 977 & $20 \%$ & 41,895 \\
\hline NC sample & 107,557 & 734 & $17 \%$ & 45,441 \\
\hline $\begin{array}{l}\text { All eligible } \\
\text { counties not in the } \\
\text { sample }\end{array}$ & 95,745 & 928 & $16 \%$ & 46,484 \\
\hline Entire sample & 117,154 & 974 & $15 \%$ & 48,653 \\
\hline
\end{tabular}

\begin{tabular}{lc|lc}
\hline \multicolumn{4}{c}{ Table 2: Respondent Experience } \\
\hline $\begin{array}{l}\text { Years of HR } \\
\text { Experience }\end{array}$ & $\begin{array}{c}\text { Count }(\%) \\
\mathrm{n}=38\end{array}$ & Years in Position & $\begin{array}{c}\text { Count }(\%) \\
\mathrm{n}=39\end{array}$ \\
\hline $\mathbf{5}$ or less & $3(8 \%)$ & $\mathbf{5}$ or less & $22(56 \%)$ \\
6 to 10 & $7(18 \%)$ & $\mathbf{6}$ to 10 & $10(26 \%)$ \\
$\mathbf{1 1}$ to 15 & $5(13 \%)$ & $\mathbf{1 1}$ to 15 & $3(8 \%)$ \\
$\mathbf{1 6}$ to 20 & $6(16 \%)$ & $\mathbf{1 6}$ to 20 & $3(8 \%)$ \\
$\mathbf{2 1}$ to 30 & $11(29 \%)$ & $\mathbf{2 1}$ to 30 & $1(3 \%)$ \\
31 and greater & $6(16 \%)$ & $\mathbf{3 1}$ and greater & $0(0 \%)$ \\
\hline
\end{tabular}

Table 3: Respondent Formal and Continuing Education

\begin{tabular}{lc|lc}
\hline Highest Degree & $\begin{array}{c}\text { Count }(\%) \\
\mathrm{n}=40\end{array}$ & Certification & $\begin{array}{c}\text { Count }(\%) \\
\mathrm{n}=40\end{array}$ \\
\hline High school diploma & $2(5 \%)$ & $\begin{array}{l}\text { No certification } \\
\text { Certification } \\
\text { (community college, } \\
\text { state, other) }\end{array}$ & $5(13 \%)$ \\
Associates & $1(3 \%)$ & $10(25 \%)$ \\
Bachelors & $20(50 \%)$ & $\begin{array}{l}\text { SHRM Certification } \\
\text { (PHR, SPHR) }\end{array}$ & \\
$\begin{array}{l}\text { Bachelors, some } \\
\text { graduate }\end{array}$ & $6(15 \%)$ & & \\
$\begin{array}{l}\text { Graduate degree (JD, } \\
\text { MPA, MBA, etc.) }\end{array}$ & $11(28 \%)$ & & \\
\hline
\end{tabular}




\begin{tabular}{|c|c|c|c|}
\hline & $\begin{array}{l}\text { Count (\%) North Carolina } \\
\mathrm{n}=20\end{array}$ & $\begin{array}{c}\text { Count }(\%) \text { New York } \\
\mathrm{n}=20\end{array}$ & $\begin{array}{l}\text { Count (\%) Entire Sample } \\
\mathrm{n}=40\end{array}$ \\
\hline \multicolumn{4}{|l|}{ Internal Resources } \\
\hline $\begin{array}{l}\text { County Attorney or Retained } \\
\text { Council }\end{array}$ & $12(60 \%)$ & $12(60 \%)$ & $24(60 \%)$ \\
\hline Executive or Executive Staff & $14(70 \%)$ & $8(40 \%)$ & $22(55 \%)$ \\
\hline $\begin{array}{l}\text { Other County Staff Subject Matter } \\
\text { Experts }\end{array}$ & $17(85 \%)$ & $17(85 \%)$ & $34(85 \%)$ \\
\hline Members of Board or Legislature & $5(25 \%)$ & $6(30 \%)$ & $11(28 \%)$ \\
\hline \multicolumn{4}{|l|}{ External Resources } \\
\hline $\begin{array}{l}\text { Personnel or Policies from other } \\
\text { Jurisdictions }\end{array}$ & $20(100 \%)$ & $16(80 \%)$ & $36(90 \%)$ \\
\hline State or Federal Agencies & $10(50 \%)$ & $12(60 \%)$ & $22(55 \%)$ \\
\hline Professional Associations & $11(55 \%)$ & $7(35 \%)$ & $18(45 \%)$ \\
\hline General Internet Search & $9(45 \%)$ & $10(50 \%)$ & $19(48 \%)$ \\
\hline Laws or General Statutes & $9(45 \%)$ & $10(50 \%)$ & $19(48 \%)$ \\
\hline $\begin{array}{l}\text { Academic Publications or } \\
\text { Personnel }\end{array}$ & $12(60 \%)$ & $0(0 \%)$ & $12(30 \%)$ \\
\hline Consultants & $3(15 \%)$ & $6(30 \%)$ & $9(23 \%)$ \\
\hline Vendors & $3(15 \%)$ & $3(15 \%)$ & $6(15 \%)$ \\
\hline Private Sector Examples & $3(15 \%)$ & $1(5 \%)$ & $4(10 \%)$ \\
\hline Books & $1(5 \%)$ & $0(0 \%)$ & $1(3 \%)$ \\
\hline
\end{tabular}




\begin{tabular}{|c|c|c|c|c|}
\hline & Minimum & Maximum & Mean & $\begin{array}{l}\text { Standard } \\
\text { Deviation }\end{array}$ \\
\hline Policy Index Score $(n=40)$ & .00 & 4.00 & 1.75 & 1.05612 \\
\hline $\begin{array}{l}\text { Use of internal working groups } \\
(n=40)\end{array}$ & .00 & 1.00 & .5250 & .50574 \\
\hline Engagement of employees $(n=40)$ & .00 & 1.00 & .175 & .3848 \\
\hline $\begin{array}{l}\text { Review of departmental implications } \\
(n=40)\end{array}$ & .00 & 1.00 & .650 & .4830 \\
\hline $\begin{array}{l}\text { Review of consistency with other } \\
\text { policies }(n=40)\end{array}$ & .00 & 1.00 & .150 & .3616 \\
\hline $\begin{array}{l}\text { Evidence-based decision-making } \\
(\mathrm{n}=40)\end{array}$ & .00 & 1.00 & .250 & .4385 \\
\hline
\end{tabular}

\begin{tabular}{|c|c|c|}
\hline \multicolumn{3}{|c|}{ Table 6: Policy Sophistication Index by Respondent and Jurisdictional Characteristics } \\
\hline & $\mathrm{n}$ & Mean \\
\hline \multicolumn{3}{|l|}{ Respondent Characteristics } \\
\hline \multicolumn{3}{|l|}{ Education $(n=40)$} \\
\hline High school or associates degree & 3 & 0.6667 \\
\hline Bachelor's & 26 & 1.6923 \\
\hline Master's or JD & 11 & 2.1818 \\
\hline \multicolumn{3}{|l|}{ Certificate $(n=40)$} \\
\hline No certifications & 25 & 1.5600 \\
\hline Has a certification & 15 & 2.0667 \\
\hline \multicolumn{3}{|l|}{ National Professional Association Membership (n=40) } \\
\hline $\begin{array}{l}\text { Not a member of national professional } \\
\text { association }\end{array}$ & 16 & 1.5000 \\
\hline Member of national professional association & 24 & 1.9167 \\
\hline \multicolumn{3}{|l|}{ Time in Position $(\mathrm{n}=39)$} \\
\hline $0-5$ years & 22 & 2.0455 \\
\hline 6 or more years & 17 & 1.2353 \\
\hline \multicolumn{3}{|l|}{ Private Sector Experience $(n=40)$} \\
\hline No & 22 & 2.0455 \\
\hline Yes & 18 & 1.3889 \\
\hline \multicolumn{3}{|l|}{ Role in County Strategic Planning $(n=40)$} \\
\hline Not a strategic partner & 24 & 1.5414 \\
\hline Strategic partner (self-reported) & 16 & 2.0625 \\
\hline \multicolumn{3}{|l|}{ County Characteristics } \\
\hline \multicolumn{3}{|l|}{ State $(n=40)$} \\
\hline North Carolina & 20 & 1.9000 \\
\hline New York & 20 & 1.6000 \\
\hline \multicolumn{3}{|l|}{ HR Department size $(n=40)$} \\
\hline $1-10$ employees & 27 & 1.6296 \\
\hline 11 or more employees & 13 & 2.0000 \\
\hline
\end{tabular}




\section{Reference List}

Adler, P.S., \& Borys, B. (1996). Two types of bureaucracy: Enabling and coercive. Administrative Science Quarterly, 41, 61-89.

Ammons, D.N., \& Rivenbark, W.C. (2008). Factors influencing the use of performance data to improve municipal services: Evidence from the North Carolina benchmarking project. Public Administration Review, 68, 304-318.

Arnaboldi, M., Lapsley, I., \& Steccolini, I. (2015). Performance management in the public sector: The ultimate challenge. Financial Accountability \& Management, 31, 1-22.

Bae, K.B., \& Yang, G. (2017). The effects of family-friendly policies on job satisfaction and organizational commitment: A panel study conducted on South Korea's public institutions. Public Personnel Management, 46, 25-40.

Battaglio, R.P., \& French, E.P. (2016). Public service motivation, public management reform, and organizational socialization: Testing the effects of employment at-will and agency on PSM among municipal employees. Public Personnel Management, 45, 123 47.

Becker, B., \& Gerhart, B. (1996). The impact of human resource management on organizational performance: Progress and prospects. The Academy of Management Journal, 39, 779801.

Benton, J. E. (2005). An assessment of research on American counties. Public Administration Review, 65, 462-474.

Bradbury, M.D, \& Facer, R.L, II. (2010). Developing practical strategies for maintaining ethical behavior. In S.E. Condrey (Ed.), Handbook of human resource management in government ( ${ }^{\text {rd }}$ ed.) (pp. 279-297). San Francisco, CA: Jossey-Bass.

Caillier, J.G. (2016). Does satisfaction with family-friendly programs reduce turnover? A panel study conducted in U.S. federal agencies. Public Personnel Management, 45, 284-307.

Clardy, A. (1997). Studying your workforce: Applied methods and tools for the training and development of practitioners. Thousand Oaks, CA: Sage.

Daley, D.M. (2006). Strategic human resource management. In N.M. Riccucci (Ed.), Public personnel management: Current concerns, future challenges $\left(4^{\text {th }} \mathrm{ed}.\right)$ (pp. 163-176). White Plains, NY: Longman.

Daley, J.L. (2012). Human resource management in the public sector: Policies and practices. Armonk, New York: M.E. Sharpe.

DeHart-Davis, L. (2009). Green tape: A theory of effective organizational rules. Journal of 
Public Administration Research and Theory, 19, 361-384.

Facer, R.L., II., \& Wadsworth, L. (2008). Alternative work schedules and work-family balance: A research note. Review of Public Personnel Administration, 28,166-177.

Facer, R.L.,II, Wadworth, L.L., \& Arbon, C.A. (2010). Alternative work schedules in local government: Cui bono? Review of Public Personnel Administration, 30, 322-340.

Fernandez, S., Resh, W.G., Moldogaziev, T., \& Oberfield, Z.W. (2015). Assessing the past and promise of the federal employee viewpoint survey for public management research: A research synthesis. Public Administration Review, 75, 382-94.

Galinsky, E., \& Stein, P.J. (1990). The impact of human resource policies on employees: Balancing work/family life. Journal of Family Issues, 11, 368-383.

Grover, S.L., \& Crooker, K.J. (1995). Who appreciates family-responsive human resource policies: The impact of family-friendly policies on the organizational attachment of parents and non-parents. Personnel Psychology, 48, 271-288.

Hall, J.L. (2017). Performance management: Confronting the challenges for local government. Public Administration Quarterly, 41, 43-66.

Hartman, J., Homer, G.W., \& Reff, A.H. (2010). The legal issues in human resource management. In S.E. Condrey (Ed.), Handbook of human resource management in government ( $3^{\text {rd }}$ ed.) (pp. 423-454). San Francisco, CA: Jossey-Bass.

Honeycutt, T. L., \& Rosen, B. (1997). Family friendly human resource policies, salary levels and salient identity as predictors of organizational attraction. Journal of Vocational Behavior, 50, 271-290

Hoyman, M.M. \& McCall, J.R. (2010). Sexual harassment. In S.E. Condrey (Ed.), Handbook of human resource management in government ( $3^{\text {rd }}$ ed.) (pp. 423-454). San Francisco, CA: Jossey-Bass

Huselid, M.A. (1995). The impact of human resource management practices on turnover, productivity, and corporate financial performance. Academy of Management Journal, $38,635-872$.

Jacobson, W.S., Sowa, J.E., \& Lambright, K.T. (2013). Do human resource departments act as strategic partners? Strategic human capital management adoption by county governments. Review of Public Personnel Administration, 44, 317-339.

Kellough, J.E. Public personnel management: A cornerstone of effective government. In N. Riccucci (Ed.), Public personnel management: Current concerns, future challenges $\left(6^{\text {th }}\right.$ ed.) (pp. 165-74). New York, NY: Routledge. 
Kim, W.C., \& Mauborgne, R. (1998). Procedural justice, strategic decision making, and the knowledge economy. Strategic Management Journal,19, 323-338.

Kopp, R. (1994). International human resource policies and practices in Japanese, European, and United States multinational companies. Human Resource Management, 33, 581-599.

Lawler E.E., III, \& Boudreau, J.W. (2009). Achieving excellence in human resources management: An assessment of human resource functions. Stanford, CA: Stanford University Press.

Ledvinka, C.B. (2010). The Americans with Disabilities Act. In S.E. Condrey (Ed.), Handbook of human resource management in government ( $3^{\text {rd }}$ ed.) (pp. 491-514). San Francisco, CA: Jossey-Bass.

Lim, S., Wang, T.K., \& Lee, S.Y. (2017). Shedding new light on strategic human resource management: The impact of human resource management practices and human resources on the perception of federal agency mission accomplishment. Public Personnel Management, 46, 91-117.

Miles, M. B., \& Huberman, A.M. (1994). Qualitative data analysis: An expanded sourcebook ( $2^{\text {nd }}$ ed.). Thousand Oaks, CA: Sage.

Mohrman, A. M., Resnick-West, S. M., \& Lawler III, E. E. (1989). Designing performance appraisal systems: Aligning appraisals and organizational realities. San Francisco, CA: Jossey-Bass.

Otenyo, E.E., \& Smith, E.A. (2017). An overview of employee wellness programs (EWPs) in large U.S. cities. Public Personnel Management, 46, 3-24.

Pfeffer, J., \& Sutton, R.I. (2006, January). Evidence- based management. Harvard Business Review, 63-74.

Phillips, K. W., Liljenquist, K. A., \& Neale, M. A. (2009). Is the pain worth the gain: The advantages and liabilities of agreeing with socially distinct newcomers. Personality and Social Psychology Bulletin, 35, 336-350.

Poister, T.H., Pasha, O.Q., \& Edwards, L.H. (2013). Does performance management lead to better outcomes? Evidence from the U.S. public transit industry. Public Administration Review, 73, 625-36.

Pugh, D.S., Hickson, D.J, \& Hinings, C.R. (1969). An empirical taxonomy of structures of work organizations. Administrative Science Quarterly, 14, 115-126.

Pynes, J.E. (2009). Human resources management for public and nonprofit organizations ( $3^{\text {rd }}$ ed.). San Francisco, CA: Jossey-Bass. 
Riccucci, N.M. (2010). Affirmative Action. In S.E. Condrey (Ed.), Handbook of human resource management in government ( $3^{\text {rd }}$ ed.) (pp. 455-474). San Francisco, CA: Jossey-Bass.

Roberts, G.E. (2003). Employee performance appraisal system participation: A technique that works. Public Personnel Management, 32, 89-98.

Roberts, G.E. (2010). Conducting practical human resource management research. In S.E. Condrey (Ed.), Handbook of human resource management in government $\left(3^{\text {rd }} \mathrm{ed}.\right)$ (pp. 735-768). San Francisco, CA: Jossey-Bass.

Rosenbloom, D.H., \& Chanin, J. (2016). What every public sector human resource manager should know about the Constitution. In R.C. Kearney \& J.D. Coggburn (Ed.), Public human resource management: Problems and prospects (pp. 16-31). Washington, DC: Sage.

Rousseau, D.M., \& Barends, E.G.R. (2011). Becoming an evidence-based HR practitioner. Human Resource Management Journal, 21, 221-235.

Rubin, E.V. (2007). The role of procedural justice in public personnel management: Empirical results from the Department of Defense. Journal of Public Administration Research and Theory, 19, 125-143.

Sabharwal, M. (2014). Is diversity management sufficient? Organizational inclusion to further performance. Public Personnel Management, 43, 197-217.

Searle, R.H., \& Ball, K.S. (2003). Supporting innovation through HR policy: Evidence from the UK. Creativity and Innovation Management, 12, 50-62.

Seawright, J., \& Gerring, J. (2008). Case selection techniques in case study research: A menu of qualitative and quantitative options. Policy Research Quarterly, 61, 294-308.

Selden, S. C. (2009). Human capital: Tools and strategies for the public sector. Washington, DC: CQ Press.

Selden, S.C., \& Moynihan, D.P. (2000). A model of voluntary turnover in state government. Review of Public Personnel Administration, 20, 63-74

Stewart, G.L., \& Brown, K.G. (2011). Human resource management: Linking strategy to practice $\left(2^{\text {nd }} e d.\right)$. Danvers, MA: John Wiley \& Sons.

Stivers, C. (2008). Governance in dark times: Practical philosophy for public service. Washington, DC: Georgetown University Press. 
Streib, G., Benton, J. E., Byers, J., Cigler, B. A., Klase, K. A., Menzel, D. C., et al. (2007). Conducting research on counties in the 21st century: A new agenda and database considerations. Public Administration Review, 67, 968-983.

Svara, J.H. (1996). Leadership and professionalism in county government. In D.C. Menzel, The American county: Frontiers of knowledge (pp. 109-27). Tuscaloosa, AL: University of Alabama Press.

Wadsworth, L.L., \& Facer, R.L. (2016). Work-family balance and alternative work schedules: Exploring the impact of 4-day workweeks on state employees. Public Personnel Management, 45, 382-404.

Whitener, E.M., Brodt, S.E., Korsgaard, M.A., \& Werner, J.M. (1998). Managers as initiators of trust: An exchange relationship framework for understanding managerial trustworthy behavior. Academy of Management Review, 23, 513-530.

Ulrich, D., Brockbank, W., Johnson, D., Sandholtz, K., and Younger, J. (2008). HR competencies: Mastery at the intersection of People and Business. Alexandria, VA: Society for Human Resource Management.

Ulrich, D., \& Brockbank, W. (2005). The HR Proposition. Boston, MA: Harvard Business School Press.

Yin, R. K. (1994). Case Study Research: Design and Methods (2 ${ }^{\text {nd }}$ ed.). Thousand Oaks, CA: Sage. 